\title{
Effects of a new cardioselective beta-adrenergic blocker (tolamolol) on exercise tolerance in patients with angina pectoris
}

\author{
N. K. SOOD and C. W. H. HA VAR D \\ Department of Medicine, Royal Northern Hospital, London
}

\begin{abstract}
The effect of oral and intravenous tolamolol on exercise tolerance was assessed in 11 patients with angina pectoris. Patients were selected on the basis of an absence of placebo response and the reliable reproducibility of anginal pain and electrocardiographic changes with exercise on a constant load Schönander-Elema bicycle ergometer. The effect of tolamolol on exercise time and heart rate was compared with that of propranolol. Tolamolol was shown to increase exercise tolerance and the effect was comparable to that of propranolol. Tolamolol did not produce a significant increase in airways resistance nor were any untoward side effects noted.
\end{abstract}

Since the beneficial effect of pronethalol in the treatment of angina pectoris was demonstrated (Dornhorst and Robinson, 1962; Alleyne et al., 1963 ; Apthorp, Chamberlain, and Hayward, 1964) several new beta-adrenergic blocking compounds have been introduced. Propranolol, the first clinically acceptable beta-blocker, has become established in the treatment of angina (Gillam and Prichard, 1965 ; Hamer and Sowton, 1966 ; Wolfson et al., 1966). Propranolol, however, reduces myocardial contractility (Chamberlain, 1966; Stephen, 1966) and causes an increase in airways resistance (McNeill, 1964) which limits its use in patients with ischaemic heart disease associated with asthma or chronic bronchitis. Practolol (Eraldin) and oxprenolol (Trasicor) are more recent beta-blockers with a more cardioselective action. Initial studies with intravenous practolol showed encouraging results (Areskog and Adolfsson, 1969) but long-term oral administration suggests that practolol is not as effective as propranolol in relieving the frequency of angina (Sandler and Clayton, 1970). This is probably due to the intrinsic sympathomimetic activity of practolol (Dunlop and Shanks, 1968). Furthermore, practolol has been shown to have negative inotropic effects on the myocardium (Gibson and Sowton, 1968 ; Sowton, Balcon, Cross, and Frick, 1968) and its use in patients with incipient cardiac failure is not without risk (Sandler and Clayton, 1970). Oxprenolol, intravenously, produces negative chronotropic and inotropic effects, although when given by mouth a negative chronotropic and a positive inotropic effect have been demonstrated in anginal subjects (Wilson et al., 1968). A single blind trial (Wilson and Turner, 1968) and a double blind trial (Wilson, Watson, Peel, and Turner, 1969) have demonstrated its effectiveness in reducing the severity and frequency of anginal attacks.

Tolamolol is a new beta-adrenergic blocking compound. In animal studies it has been found to have a cardioselective action similar to that of practolol, and it is considerably more active (Adam, 1972). It does not have the direct depressant action of propranolol on myocardial contractility (Hillis, 1973). It is, therefore, of considerable clinical interest. This study was undertaken to assess the effects of tolamolol on anginal subjects during bicycle ergometer exercise under strictly controlled conditions.

\section{MATERIALS AND METHODS}

Patients were selected on the basis of the reliable reproducibility of anginal pain and/or electrocardiographic changes with exercise on a constant load SchönanderElema bicycle ergometer. Individuals with severe angina, a history of myocardial infarction in the previous six months, severe obstructive airways disease, or cardiac failure and those with intercurrent disease likely to interfere with performance on a bicycle ergometer were excluded.

For preliminary selection each patient undertook a 
prolonged phase of familiarization with the bicycle ergometer and the requirements of the investigation. This was to ensure reproducibility of symptoms or objective electrocardiographic changes with a standard exercise test. Up to eight exercise tests were performed during this phase. Exercise loads were selected to produce pain or ECG changes within 90 to 120 seconds. Chest lead V5 was continuously monitored. Patients were trained to stop exercise at the first sign of anginal pain, or if instructed to do so when ECG changes suggestive of ischaemia were observed. Depression of the ST segment of $1 \mathrm{~mm}$ or more was considered as indicative of ischaemia. After reproducibility had been established with a selected load, response to placebo was assessed and eight patients with a positive response were excluded. Definitive studies were then carried out on 11 male patients; their ages ranged from 50 to 67 years (mean 60 years). The selected exercise load was maintained for each individual patient throughout. Precautions were taken to control factors which might alter exercise tolerance and response. Thus tests were carried out at the same time in the morning after an overnight fast. The subject rested for one hour before the test. Apprehension was overcome by the initial familiarization routine. An even temperature was maintained in the laboratory.

In the definitive single blind study the response to placebo injection of saline, to propranolol, and to tolamolol was assessed. Each patient was required to attend on four to six morning sessions. In each session two trial runs were made to ensure the continuing reproducibility of symptoms and objective ECG changes. An intravenous injection of saline was then given to reconfirm lack of response to placebo and later the active compound was tested. Propranolol was given intravenously and tolamolol both orally and intravenously in a random order. The time taken to induce angina and/or ECG changes, and the time for these changes to resolve, was recorded. Blood pressure was recorded at rest, immediately after exercise, and subsequently at 2-minute intervals. Heart rate was calculated from ECG tracings taken before exercise, at the end point, and at 15 to 30 second intervals until anginal pain disappeared or the ECG changes resolved. Further tracings were taken at one minute intervals. A rest period of 15 minutes was allowed between each run on the bicycle. Blood was collected for haemoglobin, white blood count, platelet count, and liver function tests both before and three days after intravenous tolamolol. The urine was also examined for protein and by microscopy. Forced expiratory volume in 1 second $\left(\mathrm{FEV}_{1}\right)$ was measured immediately before and after intravenous tolamolol.

The doses of propranolol used were 10 to $15 \mathrm{mg} \mathrm{I.V.}$ Tolamolol was given intravenously in doses of $7.5 \mathrm{mg}$ to $20 \mathrm{mg}$. The precise dose given was sufficient to reduce the resting heart rate to approximately 60 per minute. All patients were given a standard oral dose of $200 \mathrm{mg}$ tolamolol under supervision and exercise tests were performed one hour later.
RESULTS

The effects of different treatments on exercise time $\frac{}{\bar{s}}$ and on heart rate at rest and after exercise are $\underset{\varnothing}{\varnothing}$ shown in Tables I and II. The results re-confirm

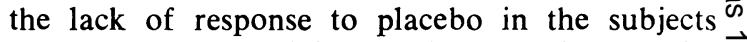
selected for the trial. The increase in exercise $\vec{O}$ tolerance with each of the active compounds ad- $\overrightarrow{\vec{\omega}}$ ministered is highly significant $(\mathrm{P}<0.001)$. The dif- $\stackrel{\omega}{\circ}$ ference in improvement of exercise time produced $\overrightarrow{\vec{x}}$ by intravenous propranolol compared to that by intravenous tolamolol was not significant.

T A B L E I

EFFECT OF DIFFERENT TREATMENTS ON EXERCISE TIME

\begin{tabular}{|c|c|c|c|}
\hline & & \multicolumn{2}{|c|}{$\begin{array}{l}\text { Differences between Exercise } \\
\text { Times on Test and Control }\end{array}$} \\
\hline & & Mean (seconds) & $\mathrm{SE}$ \\
\hline $\begin{array}{l}\text { Saline } \\
\text { I.V. propranolol } \\
\text { I.V. tolamolol } \\
\text { Oral tolamolol }\end{array}$ & $\begin{array}{ll}\ldots & \ldots \\
\cdots & \cdots \\
\cdots & \ldots\end{array}$ & $\begin{array}{l}+0.64 \\
+53.2 \\
+58.1 \\
+71.5\end{array}$ & $\begin{array}{l}=2.1 \\
=6.1 \\
=8.6 \\
=7.0\end{array}$ \\
\hline
\end{tabular}

${ }^{1}$ Calculated from individual values of control minus test for 11 patients

T A B L E I I

EFFECT OF DIFFERENT TREATMENTS ON HEART RATE

\begin{tabular}{|c|c|c|c|c|}
\hline & \multicolumn{4}{|c|}{$\begin{array}{c}\text { Difference between Heart Rate on } \\
\text { Test and Control }\end{array}$} \\
\hline & \multicolumn{2}{|c|}{ Resting } & \multicolumn{2}{|c|}{ Post-exercise } \\
\hline & Mean & SE & Mean & SE \\
\hline $\begin{array}{l}\text { Saline } \\
\text { Propranolol } \\
\text { I.V. tolamolol } \\
\text { Oral tolamolol }\end{array}$ & $\begin{array}{l}+0.09 \\
-14.4 \\
-16.9 \\
-17.8\end{array}$ & $\begin{array}{l} \pm 1 \cdot 0 \\
=2.6 \\
\pm 3 \cdot 1 \\
\pm 3 \cdot 1\end{array}$ & $\begin{array}{l}+0.36 \\
-21 \cdot 2 \\
-24 \cdot 8 \\
-26.5\end{array}$ & $\begin{array}{l} \pm 1 \cdot 1 \\
\pm 2 \cdot 7 \\
\pm 3 \cdot 0 \\
\pm 2 \cdot 3\end{array}$ \\
\hline
\end{tabular}

${ }^{1}$ Calculated from individual values of control minus test for 11 patients

The duration of angina and ECG changes were also recorded in control and placebo (intravenous $\frac{}{\partial}$ saline) studies. In some patients after tolamolol $\rightarrow$ angina could not be induced despite the fact that they were exercised to the point of physical ex- N haustion. In those patients in whom it could be induced with exercise the duration of angina and ECG changes were considerably reduced.

In control studies the end point of exercise was anginal pain in five patients and ST segment de- 0 pression in six. Neither angina nor ECG changes $\mathbb{D}$ could be induced in five patients after propranolol, ? in six patients after intravenous tolamolol, and in ${ }^{\circ}$ five patients after oral tolamolol. In each instance $\frac{0}{\mathbb{D}}$ the patient exercised to the point of physical exhaustion and this was taken as an arbitrary end $\stackrel{\varnothing}{2}$ point.

No significant lowering of blood pressure at rest or after exercise was observed after any of 
the compounds administered. No untoward side effects were recorded. There were no significant changes in the blood count, liver function tests or urinalysis.

Of the eight patients in whom $\mathrm{FEV}_{1}$ was measured, it was slightly lower in five, higher in two, and remained unaltered in one (Table III).

\section{T A B L E I I I}

\begin{tabular}{c|c|c}
\hline \multirow{2}{*}{ Patient } & \multicolumn{2}{|c}{ FEV } \\
\cline { 3 - 3 } \cline { 3 - 3 } & Before i.v. Tolamolol & After i.v. Tolamolol \\
\hline 1 & $3 \cdot 50$ & $3 \cdot 40$ \\
2 & $3 \cdot 10$ & $3 \cdot 25$ \\
3 & $3 \cdot 20$ & $2 \cdot 80$ \\
4 & $2 \cdot 65$ & $2 \cdot 40$ \\
5 & $3 \cdot 30$ & $3 \cdot 25$ \\
6 & $3 \cdot 15$ & $2 \cdot 95$ \\
7 & $2 \cdot 80$ & $2 \cdot 90$ \\
8 & $3 \cdot 30$ & $3 \cdot 30$ \\
Mean & $3 \cdot 125$ & $3 \cdot 03$ \\
\hline
\end{tabular}

\section{DISCUSSION}

A method of exercise testing to assess the antianginal effect of tolamolol was chosen because this provides more useful data and more reliable results than a carefully designed double blind trial in which it is always difficult to exclude a placebo response and other factors beyond the control of the investigator (Cole and Goldberg, 1967; Datey and Dalvi, 1970; Redwood et al., 1971). All patients showing any placebo response were excluded from the investigation. While it is uncertain how the results obtained with bicycle ergometry relate to everyday activity, this technique has the virtue of reproducibility under controlled conditions. Our results show that both propranolol and tolamolol are effective in increasing exercise tolerance in patients with angina pectoris. The favourable effects of tolamolol are comparable to those of propranolol and are evident following both oral and parenteral administration. The difference in exercise tolerance between oral and intravenous tolamolol $(\mathrm{P}<0.005)$ may be due to the difference in effective doses of the drug. It is possible that smaller effective doses were given parenterally compared to the standard oral dose of $200 \mathrm{mg}$ given to all patients.

The mechanism of action of tolamolol involves blockade of cardiac sympathetic beta receptors. Haemodynamic studies have now shown that although it has a slight negative inotropic effect, this is not associated with a reduction in cardiac contractility (Hillis, 1973). The mean percentage increase in effort tolerance in our studies was $74 \%$ with propranolol, $81 \%$ with intravenous tolamo- lol, and $101 \%$ with oral tolamolol. The percentage increment with propranolol is higher than that of previous reports using exercise tolerance (Areskog and Adolfsson, 1969 ; Hamer, Grandjean, Melendez, and Sowton, 1964). This is due to the method of testing which produced an early end point to exercise and any increase in exercise tolerance therefore became proportionally large.

The present study shows that tolamolol increases the exercise tolerance of patients with angina pectoris. Furthermore, doses of tolamolol capable of blocking cardiac beta receptors do not produce a significant increase in airways resistance in patients who do not suffer from asthma. This is an important advantage over propranolol. Further studies are now required to confirm the clinical efficacy of this drug in the long-term treatment of angina pectoris.

We are grateful to Dr. Douglas Chamberlain for helpful advice and to Mr. Michael Curwen for statistical help.

\section{REFERENCES}

Adam, K. R. (1972). Personal communication.

Alleyne, G. A. O., Dickinson, C. J., Dornhorst, A. C., Fulton, R. M., Green, K. G., Hill, I. D., Hurst, P., Laurence, D. R., Pilkington, T., Prichard, B. N. C., Robinson, B., and Rosenheim, M. L. (1963). Effect of pronethalol in angina pectoris. Brit. med.J., 2, 1226.

Apthorp, G. H., Chamberlain, D. A., and Hayward, G. W. (1964). The effects of sympathectomy on the electrocardiogram and effort tolerance in angina pectoris. Brit. Heart J., 26, 218.

Areskog, N. H., and Adolfsson, L. (1969). Effects of a cardioselective beta-adrenergic blocker (I.C.I. 50172) at exercise in angina pectoris. Brit. med. J., 2, 601.

Chamberlain, D. A. (1966). Haemodynamic effects of betaadrenergic blockade in man. Cardiologia, 49, Suppl. 2, p. 27.

Cole, R. E., and Goldberg, R. I. (1967). Timed-release pentaerythritol tetranitrate and placebo in the management of angina pectoris. Curr. ther. Res., 9, 551.

Datey, K. K., and Dalvi, C. P. (1970). Anti anginal drugs, their evaluation by double blind trial. Angiology, 21, 520 .

Dornhorst, A. C., and Robinson, B. F. (1962). Clinical pharmacology of a beta-adrenergic-blocking agent (nethalide). Lancet, 2, 314.

Dunlop, D., and Shanks, R. G. (1968). Selective blockade of adrenoceptive beta receptors in the heart. Brit. $J$. Pharmacol., 32, 201.

Gibson, D., and Sowton, E. (1968). Effects of I.C.I. 50172 in man during erect exercise. Brit. med. J., 1, 213.

Gillam, P. M. S., and Prichard, B. N. C. (1965). Use of propranolol in angina pectoris. Brit. med.J., 2, 337.

Hamer, J., Grandjean, T., Melendez, L., and Sowton, G. E. (1964). Effect of propranolol (Inderal) in angina pectoris: preliminary report. Brit. med. J., 2, 720. 
Hamer, J., and Sowton, E. (1966). Effects of propranolol on exercise tolerance in angina pectoris. Amer. J. Cardiol., $18,354$.

Hillis, S. (1973). The effects of a new beta-adrenoceptor blocking compound, Tolamol, on haemodynamic and myocardical function in man. Brit. J. Pharmacol. (in press).

McNeill, R. S. (1964). Effect of a $\beta$-adrenergic-blocking agent, propranolol, on asthmatics. Lancet, 2, 1101.

Redwood, D. R., Rosing, D. R., Goldstein, R. E., Beiser, G. D., and Epstein, S. E. (1971). Importance of the design of an exercise protocol in the evaluation of patients with angina pectoris. Circulation, 43, 618.

Sandler, G., and Clayton, G. A. (1970). Clinical evaluation of practolol, a new cardioselective beta-blocking agent in angina pectoris. Brit. med. J., 2, 399.
Sowton, E., Balcon, R., Cross, D., and Frick, H. (196\& Haemodynamic effects of I.C.I. 50172 in patients wi莭 ischaemic heart disease. Brit. med.J., 1, 215.

Stephen, S. A. (1966). Unwanted effects of propranolon Amer. J. Cardiol., 18, 463.

Wilson, D. F., and Turner, A. S. (1968). Trasicor $(39,089$ $\mathrm{Ba}$ ) in angina pectoris. A single-blind trial. N.Z. med. 67, 406.

Watson, O. F., Peel, J. S., Langley, R. B., and Turner A. S. (1968). Some haemodynamic effects of Trasicøo (Ciba 39,089 Ba). N.Z. med. J., 68, 145.

and Turner, A. S. (1969). Trasicor in angin pectoris: a double-blind trial. Brit. med. J., 2, 155.

Wolfson, S., Heinle, R. A., Herman, M. V., Kemp, H. Sullivan, J. M., and Gorlin, R. (1966). Propranolol an angina pectoris. Amer.J. Cardiol., 18, 345. 